\title{
街なみ環境整備事業を利用した壁面後退と修景による住環境・景観整備
} 一総社商店街地区を事例に-

\section{LIVING ENVIRONMENT AND LANDSCAPE MAINTENANCE DUE TO RESTORATION AND SETBACK USING THE UNDERTAKING FOR TOWNSCAPE IMPROVEMENT}

A case study on the Soja shopping streets area

\author{
井上 亮*, 中野茂夫** \\ Ryo INOUE and Shigeo NAKANO
}

\begin{abstract}
Only a few undertakings for townscape improvement have been integrally completed in combination with restoration of housing and setbacks. We studied the shopping district of Soja city to discuss the realities and problems of undertaking townscape improvement with reference to MACHIDUKURI agreements and clarified the following problems.

Restorations were mostly based on a MACHIDUKURI agreement, but buildings that were not restored in the undertaking for townscape improvement failed to solve problems with the landscape. Utilization of space created by the setbacks is still an issue to be solved. Spaces for relaxing inside the district were scarcely improved.
\end{abstract}

Keywords: Soja City, Undertaking for townscape improvement, Shopping street, Restoration, Setback 総社市，街なみ環境整備事業，商店街，修景，壁面後退

\section{1.はじめに}

近年、重要伝統的建造物群保存地区や景観地区だけでなく、市街 地においても行政支援による修景事業が実施され、良好な街なみの 維持・保全や景観の向上に力が注がれている。修景の方法として、 街なみ環境整備事業（以下「街環事業」）や集約促進景観・歴史的風 致形成推進事業など国土交通省が定める要件を満たすことで補助金 等の支援を受けることができる施策があげられる。特に、街環事業 は区域内の住民の合意によって締結される「街づくり協定」注1) が あり、住民主体型の事業として位置付けられる。

ところで、街環事業の特徴は、良好な街なみの形成に必要となる 小公園の設置や道路の美装化、住宅等の修景を行うことができる点 にあるが、建物の修景と道路拡幅を一体的に行っている地区の事例 はほとんどない注2)。道路拡幅を行う手法の一つに壁面後退いわゆる セットバックがある注3)。この手法を取り入れている地区として岡山 県総社市の「総社商店街地区」がある。総社商店街地区は、公園が 全くなく、幅員 $6 \mathrm{~m}$ 以上の道路も道路総延長の 1 割にも満たない。そ こで、道路拡幅を行うために建物の壁面後退を実施している。当地 区の壁面後退は、建築基準法による壁面後退とは異なり、後退した 部分を道路として利用するのではなく、敷地として利用するもので ある。このように道路の公的領域と建物の私的領域の中間に位置す る半公共的空間をつくることで、道路幅員を確保することが可能と なった。また、壁面後退にあわせて建物の修景も行っている。この 手法は、壁面後退によって創出された半公共的空間を使った景観整
備の事例として位置付けられる。このように壁面後退によりできた 総社商店街地区の街なみを整備手法、事業実績、現在の活用状況の 観点から明らかにすることで、街環事業の新たな計画手法の提案に もつながると考えられる。

街環事業に関しては、鵤ら（2004） 1) による事業制度の運用・実

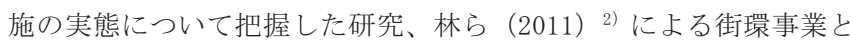
景観施策の関係性について東海 3 県を事例に明らかにした研究はあ るが、街環事業によって整備された建築物や外構空間の整備・活用 について具体的に詳述した研究はほとんどない。また、セットバッ ク方式という壁面後退の手法により市街地全域に亘って街路空間を 整備している例として、井上ら（2016） ${ }^{3)}$ による岡山市の事例があ る。このセットバック方式は、街環事業とは異なり、補助金がなく、 無償で後退する手法である。

以上をふまえ、本稿では、総社商店街地区を事例に取り上げ、建 物の修景と壁面後退を一体的に行うことで創出された街路空間の整 備状況と活用の実態について明らかにし、今後に向けた提言を行う ことを目的とする。

研究方法としては、「総社商店街地区多機能交流拠点整備事業調查 報告書」4）注4) 及び総社市図書館所蔵「総社商店街地区街なみ環境 整備事業街な夕環境整備方針報告書（事業期間 15 年間）」(平成 9 年〜平成 23 年) ${ }^{5)}$ をもとに街環事業が行われる前の総社商店街地区 について整理し、街環事業に至った経緯や当時の問題点などを把握 する。ついで、「総社商店街地区街づくり協定」に照らし合わせて、

* 島根大学大学院総合理工学研究科 助教 - 博士 (工学)

** 島根大学大学院総合理工学研究科 教授·博士(都市 · 地域計画) 
(1)壁面後退、(2)色彩 (外壁の彩度)、(3)外壁材等（漆喰、木製格子）、 (4)門・塀、(5)屋根 (勾配、材料)、(6)建築物以外の要素（駐車場、空 き地）の 6 項目に大別して調查・分析を行い、「街づくり協定」の問 題点を抽出した上で達成度と妥当性について検証する注5)。調査・分 析については修景事例を中心に行うが、地区全体の現状についても 把握する必要があるため、あわせて検討する。また、当地区では (1) 生活道路、（2）小公園（ポケットパーク）、（3）コミュニティ施設、 （4）道路の付属施設の 4 つに分けて計画・整備されているため、こ れらについても現在の整備・活用について明らかにする。なお、(4) 道路の付属施設は、公共用地の一部に親水空間が計画されたが、小 公園として整備されたため、（2）小公園において記述している。

\section{2. 総社商店街地区の概要}

総社商店街は、もともと総社宮の門前町として栄えていた。中心 市街地の北東部に位置し、西から田町 (旧東田町)、本町、栄町、西

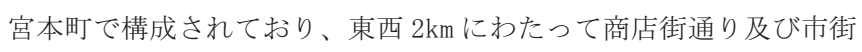
地が細長く延びている。街環事業地区には、田町、本町、栄町が該 当している。写真 $1-1 \sim 3$ をみると、 どの地区においても幅員が狭く、現 在も後退していない建物が多いこと がわかる。この地区は、当地区の関 係権利者で組織する「門前まちをよ くする会」を中心として、市・商工 会議所・市内建築士の協議により決 定した注6)。

昭和 10 年頃の商店街は、街なみの 連続性が高く、寿座や総社劇場とい った施設も充実しており ${ }^{4)}$ 注7)、昭和 40 年代前半までは総社市の中心地 であり、昭和 43 年〜 46 年には商店 街通りにアーケードも建設された (写真 2)。しかし、昭和 40 年代後

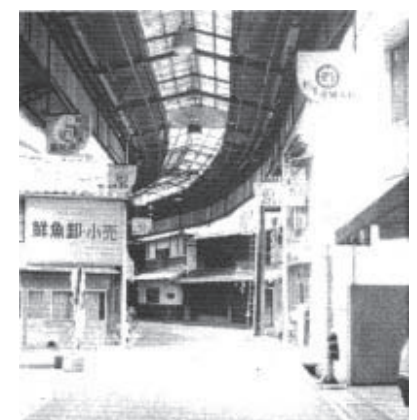

写真 2 アーケード(田町地区) - 総社市・財団法人国土開発技術研 究センター「総社商店街地区多機能 交流拠点整備事業調查報告書」 (1991. 3)。
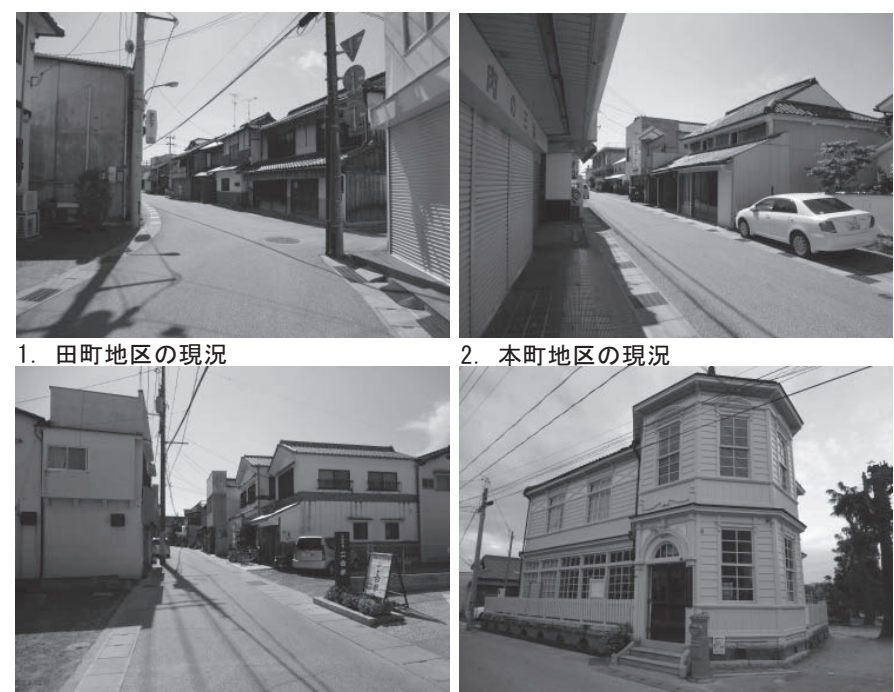

2. 本町地区の現況

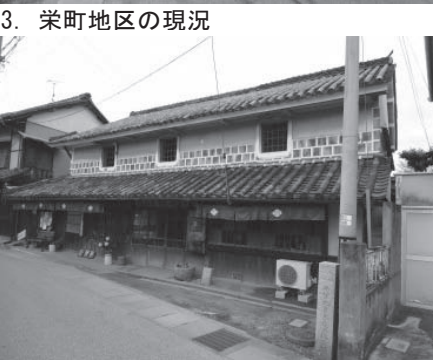

4. 旧総社警察署

5. 旧堀和平邸

写真 1 商店街通り沿いの街なみと主要な建築物

・筆者が平成 27 年 12 月に撮影したものである。

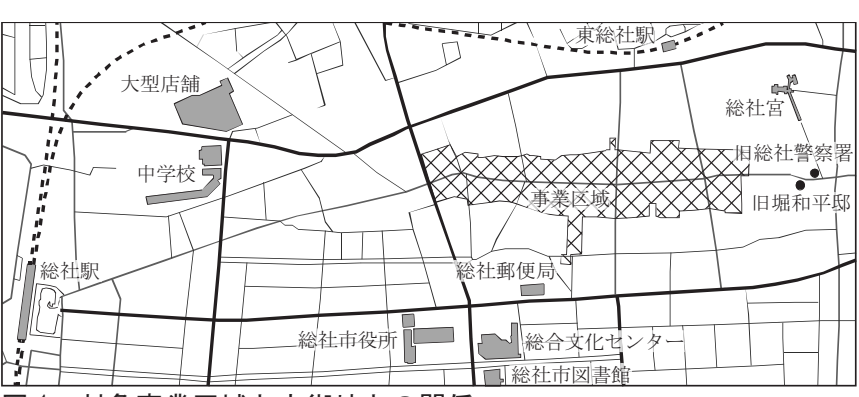

図 1 対象事業区域と市街地との関係

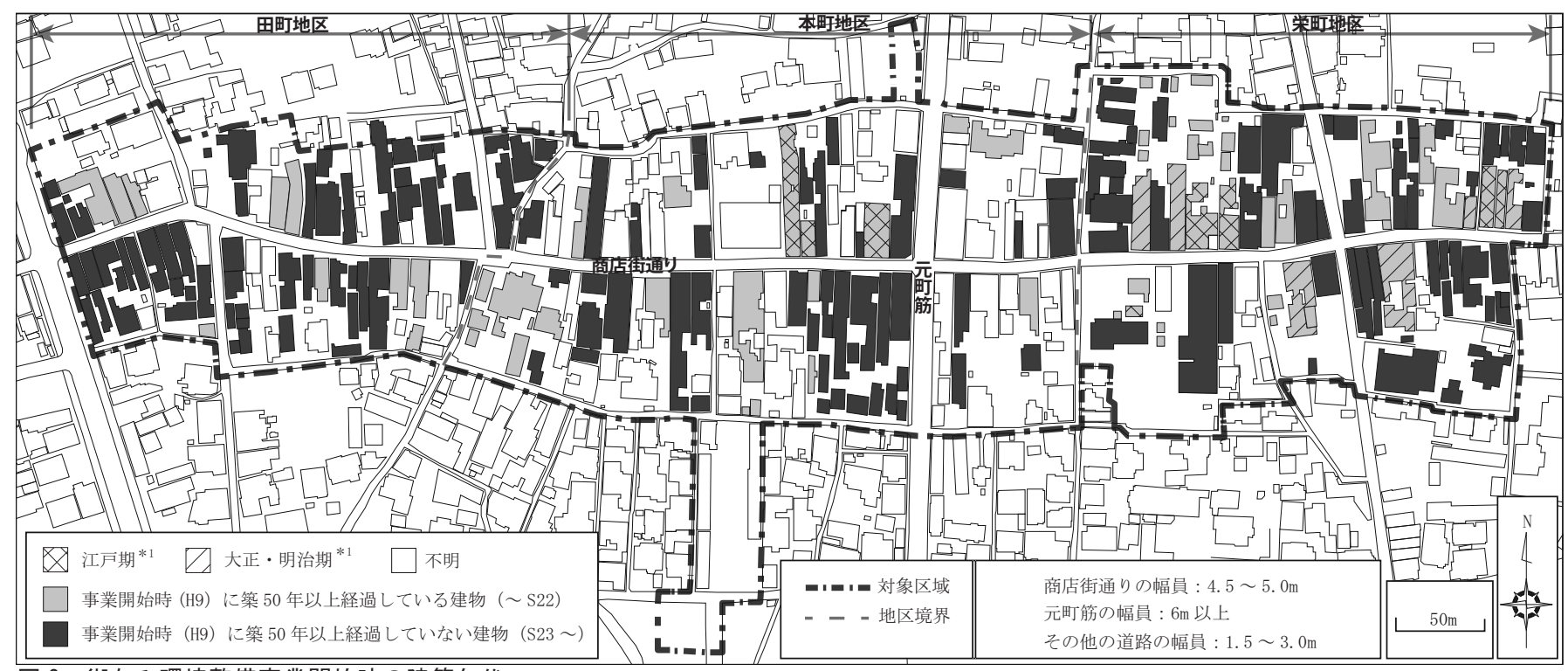

図 2 街なみ環境整備事業開始時の建築年代

・総社市「総社商店街地区街なみ環境整備事業 街なみ環境整備方針報告書」（1995.3）及び街なみ環境整備事業開始前の総社市都市計画図をもとに作成した。 *1: 時代がわかる建物については、網掛けした。 
半からは、総社駅前の区画整理事業により主要な公共施設が駅前に 順次移転していった。さらに、駅前の大型店舗建設により、田町地 区を中心に商店街は衰退化し、シャッター商店街となっていった。 一方で、栄町地区は比較的開店している店舗が多く残った（図 1)。 事業開始時（平成 9 年）の地区内の建築年代をみてみると、田町・ 本町地区は、築 50 年に満たない建物が多いが、栄町地区は、大正・ 明治・江戸期の建物がいくつか残っており、昔の面影を残している (図 2)。また、栄町地区の東側には、旧総社警察署（明治 43 年築・ 現まちかど郷土館）（写真 1-4、図 1） や旧堀和平邸（天保 14 年築） （写真 1-5、図 1) がある。現在は、これらの遺構は観光資源として 活用されているが、街環事業地区の区域外に位置している。

街環事業地区の面積は、7.0ha で、東西約 600m、南北約 100〜150m の細長い区域となっている。商店街の中心を東西に貫く街路は、幅 員 $4.5 \sim 5 \mathrm{~m}$ で、南北には元町筋（幅員 $6 \mathrm{~m}$ 以上）が通っている。しか し、その他の道路の幅員は、1.5〜3m となっており、緊急車両の通 行が困難となっている。区域内に建つ建物の約 9 割 ${ }^{4)}$ は、木造とな っており（図 3)、老朽化や防災面が問題となっている。また、アー 表 1 街なみ環境整備事業実施に至るまでの流れ

\begin{tabular}{|c|c|c|c|}
\hline 年 & 月 & 日 & 事柄 \\
\hline S61 & 5 & 24 & 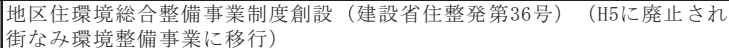 \\
\hline S63 & 4 & 7 & $\begin{array}{l}\text { 街なみ整備促進事業創設（建設省住整発第41号）（H5に廃止され街なみ環 } \\
\text { 境整備事業に移行） }\end{array}$ \\
\hline \multirow{2}{*}{ H5 } & 4 & 1 & 街なみ環境整備事業創設（建設省住整発第27号） \\
\hline & 8 & - & 商店街通りのアーケード撤去 \\
\hline \multirow{9}{*}{$\mathrm{H} 6$} & 6 & 6 & 第1回役員会 \\
\hline & 9 & 7 & $\begin{array}{l}\text { 総社市へ平成6年度街なみ環境整備事業補助金交付申請提出（協議会活動 } \\
\text { 助成金） }\end{array}$ \\
\hline & 9 & 16 & 第4回役員会（予算案の決定） \\
\hline & 9 & 19 & $\begin{array}{l}\text { 総社市より平成6年度街なみ環境整備事業補助金交付決定通知（総社市指 } \\
\text { 令都第391号) }\end{array}$ \\
\hline & 9 & 26 & 総社市より平成6年度街なみ環境整備事業補助金交付（300万円） \\
\hline & 10 & 4 & $\begin{array}{l}\text { 第5回役員会（まちづくりニュース（第2号）でモデルプランの申し込みを } \\
\text { 受け付け }\end{array}$ \\
\hline & & & $\begin{array}{l}\text { 第6回役員会（モデルプラン希望状沉：建替7件、修景4件、建築家に対し } \\
\text { モデルプラン作成をおお願いする (予算200万円、8件) } \\
\end{array}$ \\
\hline & 10 & 12 & $\begin{array}{l}\text { 第 } 1 \text { 回理事会 (会の名称「門前まちを良くする会」、標語の決定、標語を } \\
\text { 入れた横断幕6個作成、研修視察として東京都足立区、仙台市に視察) }\end{array}$ \\
\hline & 10 & 29 & 第7回役員会（現況調査報告、モデルプラン作成） \\
\hline $\mathrm{H} 7$ & 3 & 7 & 第14回役員会（各町内会報告） \\
\hline
\end{tabular}

ケードは、シャッターの閉まった空き店舗の連続と老朽化したアー ケードに覆われた薄暗い雰囲気が景観の悪化を招く要因であるとし て、街環事業開始前の平成 5 年 8 月に撤去された。当地区は、駅前 の大型店舗建設やアーケード撤去等により商店数は年々減少し、平 成 27 年には 27 件のみとなった。（表 3 )。現在は、住宅が多くを占 めており、商店も点在していることから商店街としての機能が失わ れているため、本稿では商店街としての考察は行わないものとする。

\section{3. 街なみ環境整備事業の計画経緯と補助金}

街環事業は、住環境の整備改善を必要と寸る区域において、地方 公共団体及び「街づくり協定」を結んだ住民が協力して美しい景観 の形成、良好な居住環境の整備を行うことを支援する事業である ${ }^{6)}$ 。 特に、活力の低下した中心市街地や商店街、歴史的な地区に適用さ れている。総社商店街地区は、住宅が密集しており、建物の老朽化 や生活道の未整備の問題のほか、準防火地区の指定を受けており火 災時の対応が懸念されるため、「昔の風情を残した街なみの保全と火 災時の通用道の確保」を目的として、住民と一体となって、ゆとり 表 2 全国共通の街なみ環境整備促進区域の要件

\begin{tabular}{|c|c|c|}
\hline \multicolumn{2}{|r|}{ 街なみ環境整備促進区域 } & 総社商店街地区 \\
\hline \multicolumn{2}{|r|}{ 面積 1 ha以上かつ、次の3つのいずれかの要件に該当する区域等 } & 7. Oha \\
\hline \multirow{2}{*}{ I } & •·接道不良住宅率 $70 \%$ & $21.4 \%$ \\
\hline & ·住宅密度 30戸/ha以上 & 28戸/ha \\
\hline \multirow[b]{2}{*}{ (II) } & •幅員 $6 \mathrm{~m}$ 以上の道路の延長が道路総延長の $25 \%$ 未満 & $6.12 \%$ \\
\hline & ·公園等の面積の合計＼cjkstart面積の $3 \%$ 未満 & $0 \%$ \\
\hline III & $\begin{array}{l}\text { ·観計画区域または景観地区を含む区域、歴史的風致維持向上 } \\
\text { 計画の重点区域を含む区域、及び条例等により景観形成を図る } \\
\text { こきこととされている域 }\end{array}$ & $x$ \\
\hline \multicolumn{2}{|r|}{ 街なみ環境整備事業地区 } & \\
\hline i & - 街なみ環境整備促進区域内において、地区面積0. $2 \mathrm{ha}$ 以上 & 7. Oha \\
\hline ii & ·土地所有者等による「街づくり協定」が締結されている地区 & $\begin{array}{c}\text { 平成9（1997）年 } \\
\text { 10月31日締結 }\end{array}$ \\
\hline \multicolumn{3}{|c|}{$\begin{array}{l}\text { ・総社市「総社商店街地区街なみ環境整備事業 街なみ環境整備方針報告書」 } \\
\text { (1995.3) 及び総社市「総社商店街地区街づくり」、国土交通省住宅局「街な } \\
\text { み環境整備事業パンフレット」より作成。 } \\
\text { ・接道不良住宅とは、幅員 } 4 \mathrm{~m} \text { 以上の道路に接していない住宅のことである。 }\end{array}$} \\
\hline
\end{tabular}

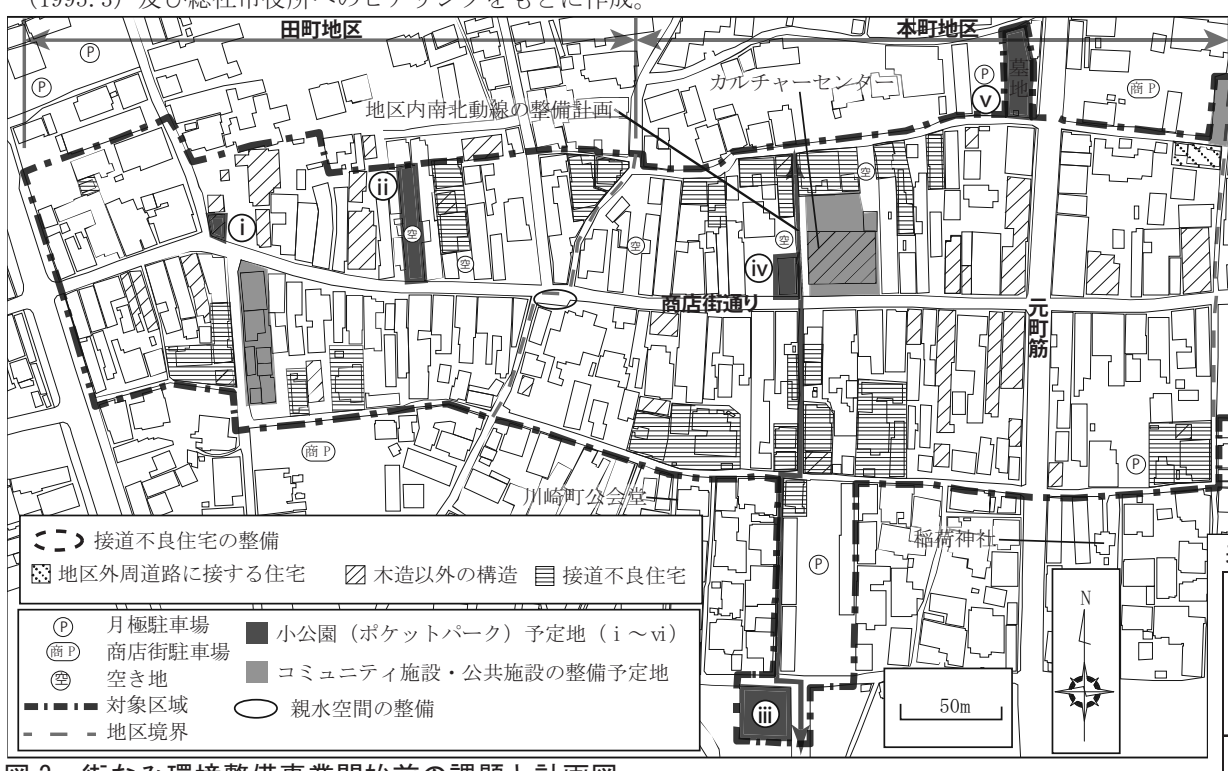

\section{図 3 街なみ環境整備事業開始前の課題と計画図}

・総社市「総社商店街地区街なみ環境整備事業 街なみ環境整備方針報告書」（1995.3）及び街なみ環境整備 事業開始前の総社市都市計画図をもとに作成した。地区外周道路に接する住宅とは、幅員 $4.0 \mathrm{~m}$ 以上の地区外 周道路に接する住宅のことをいう。 $\mathrm{i}$ 〜 vi 5 章と対応している。

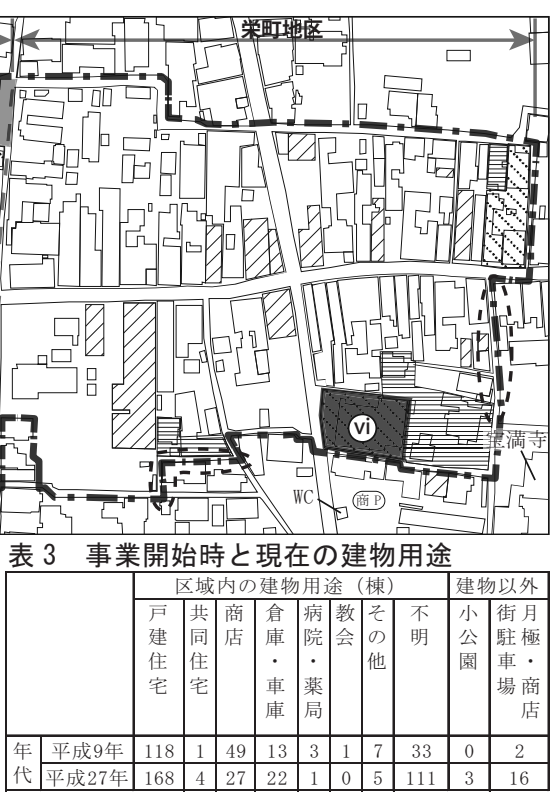

各年代のゼンリン住宅地図及び現地調查をもと に集計したもので、通り沿いから目視により用途 が判断できなかった建物は不明とした。その他 は、会社、集会所、老人ホーム、工場等である。 
と潤いのある住宅地を実現するため、街環事業が実施されることに なった注8)。

街環事業が実施されるまでの経緯として (表 1)、平成 6 年 6 月 6 日に第 1 回役員会（門前まちをよくする会）が開かれ、街環事業に ついて市の職員と商店街役員により話し合われた。第 3 回役員会で は、総社市と岡山市からそれぞれ 2 名ずつ建築家が参加し、モデル プランについて検討した。その後、9月19日に街環事業補助金交付 決定通知を受けた（総社市指令都第 391 号、300万円）。街なみ環境 整備方針の標語として、「心のやすらぐ散歩道」、「きびの里、みどり の風を運ぶまち」をかかげ、事業を進めていった。10月 4 日には、 街環事業初年度の建替・修景着工に先立って、まちづくりニュース を発刊し、モデルプランの申し込みを受け付けた。これにより、建 替 7 件、修景 4 件の希望者がでた。これを受けて、役員会では、建 築家に対して予算 200 万円、計 11 件のうち 8 件の基本設計となるモ デルプランの作成を依頼した。役員会では、街環事業の事例を見学 するために東京都足立区と仙台市の 2 班に分かれて視察した。参加 者は、役員、理事、建替 - 修景希望者の中から、6 7 人と市の職員 が同行し、1 泊 2 日で研修視察が行われた。視察の報告では、小公 園が小さ寸ぎることや道路を $4.0 \mathrm{~m}$ に拡幅していたことが報告され たが、実際に当該地区で街環事業を実施する際は、全国的にも実施 例がほとんどなかったため、特に参考にした都市はないという注7)。

街環事業は、表 2 に定める一定の要件を満たさなければならない。 総社商店街地区の接道不良住宅は、総住宅数 187 件中 40 戸で、 $21.4 \%$ だった（図 3) 注9)。特に、本町地区では 40 戸中 24 戸が接道不良住 宅となっており、主要通りである商店街通りの裏道において多数存 在していた。しかしながら、街環事業促進区域の要件 I は、満たさ なかった。一方で、区域内の幅員 $6 \mathrm{~m}$ 以上の道路の延長が区域内の道 路総延長の $6.12 \%$ しかなく、公園、広場及び緑地が全くない。その ため、総社商店街地区は、要件 II で採択された。また、土地所有者 等の合意による「街づくり協定」を締結する必要があり、平成 9 年 10 月 31 日に総社市から承認された。総社商店街地区では、表 4 の ように「街づくり協定」を定めており、街なみ環境整備事業制度要 綱第 9 に掲げられた以下の事項を定めなければならない。

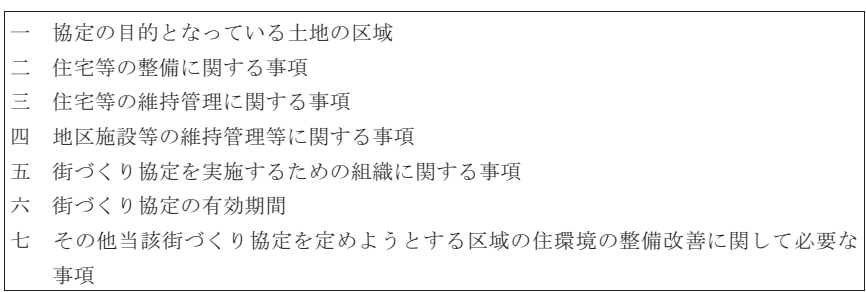

上記の項目を満たした上で、地域特性にあわせて項目が追加され るため、「街づくり協定」は、独自性のある協定となる。具体的には、 住宅等や敷地において、形態意匠の統一、壁面線の指定、敷地の整 備のうち 1 項目以上を必ず定める必要がある。その上で具体的な数 值等が定められているため、詳細な協定となっている。壁面の位置 をそろえることにより街なみの統一性を形成している地区が一定数 あるなかで、総社商店街地区は、後退距離 $2 \mathrm{~m}$ 以上という上限值のな い具体的な数值を提示した上で、半公共的空間を使った緑化等の景 観整備を計画しており、独自性が高い修景基準といえる。

以上のような修景基準とあわせて次のような計画がたてられた。 総社商店街地区では前述のように公園、広場及び緑地が全くなかっ
たため、6 箇所の小公園の整備が行われることになった。街環事業 地区内では、公共施設の用に供している土地は 0.3 ha だったため注10)、 コミュニティ施設や公共施設がほとんどなく、本町地区の中心に位 置する集会所だけだった（写真 1-6）。そのため、コミュニティ施設 や公共施設の計画がたてられた。商店街通りのアーケードを撤去し たことや道路の老朽化により、道路の美装化も計画された。商店街 通り以外の $4.0 \mathrm{~m}$ 以上の幅員がある道路は、一部を除いて舗装の整備 と建築物のファサード整備・敷地の整備が予定された。

壁面後退を行うに至った経緯は、地区内の街路の状況から、現在 の公共空間だけでは、㮩いの場や緑化などの潤い空間の演出が不可 能であると判断し、修景や建替えにより私的領域の視覚的解放が必 要であると考えられた。壁面後退した後の後退した部分の利用方法 として、道路として利用するか、もしくは敷地として利用するかの 2 種類が考えられた。本事業の商店街通りでは、敷地として利用す る方法が採用された（図 4)。これは建築基準法による道路後退とは 異なる手法となっている。具体的には、建物の壁面後退や低い塀等 により前庭の一部を視覚的に公共空間に提供することにより実現し た。道路として利用する方法については、道路と一体的に整備でき、 景観も統一できるが、 奥行きの小さい敷地で は大規模な修景をして も幅員を確保すること が不可能であるため採 用に至らなかった。

平成 9 年度 平成 23 年度の補助対象事業費

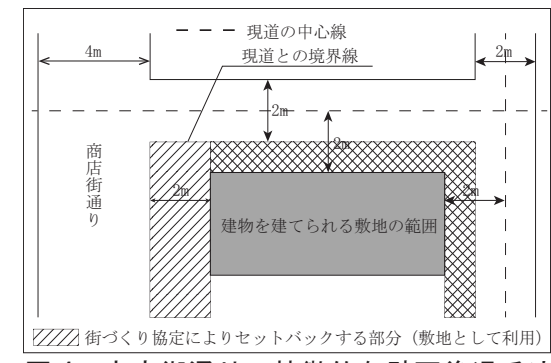

図 4 商店街通りの特徵的な壁面後退手法

\section{表 4 街づくり協定の整備方針}

\begin{tabular}{|c|c|}
\hline $\begin{array}{l}\text { 建物の壁 } \\
\text { 面後退 }\end{array}$ & 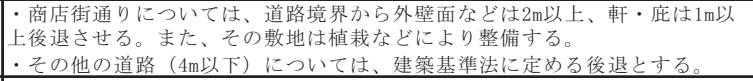 \\
\hline $\begin{array}{c}\text { 建物の色 } \\
\text { 彩 }\end{array}$ & 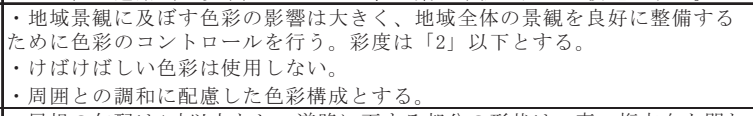 \\
\hline $\begin{array}{c}\text { 建物の屋 } \\
\text { 根 }\end{array}$ & $\begin{array}{l}\text { ·屋根の勾配は4寸以上とし、道路に面する部分の形状は、妻、桁方向を問わ } \\
\text { ない。 } \\
\text { • 無彩色の瓦が望ましい。 }\end{array}$ \\
\hline $\begin{array}{l}\text { 建物の外 } \\
\text { 壁 }\end{array}$ & $\begin{array}{l}\text { ·外壁面積の } 25 \% \text { 以上を漆喰又は、これに類する仕上げとする。 } \\
\text { ·無彩色とする。 } \\
\text { 空格子など木を積極的に採用するが、金属材料を使用する場合にはこれに } \\
\text { 類した仕上げとする。 }\end{array}$ \\
\hline $\begin{array}{l}\text { 建物の化 } \\
\quad \text { 粧材 }\end{array}$ & $\begin{array}{l}\cdot \text { ·゙きるだけ木材を使用する。 } \\
\text { ·木材の特徴を生かした素地仕上げとする。 } \\
\text { ·垂木、軒先、付け柱、空朹、格子等。 } \\
\end{array}$ \\
\hline $\begin{array}{c}\text { 建築材料 } \\
\text { 全般 } \\
\end{array}$ & $\begin{array}{l}\text { ·石、木材、漆喰等の自然素材をできるだけ多く使用する。 } \\
\text { ·地域景観の質を高めるように材料の選択と使用方法に配慮する。 }\end{array}$ \\
\hline 門塀等 & $\begin{array}{l}\text { ·建物全体と調和した色彩・材質・形態とし周囲の景観と調和したものとす } \\
\text { る。植栽を行う場合は、市の木「モミジ」、市の花「サツキ」を含めることが } \\
\text { 望まし道路側の 敷地の仕上げは、石、木、煉瓦などの自然素材を使用すること。 } \\
\cdot \text { 車庫のシャッターは、木製あるいはそれ類するものとする。 } \\
\end{array}$ \\
\hline その他 & 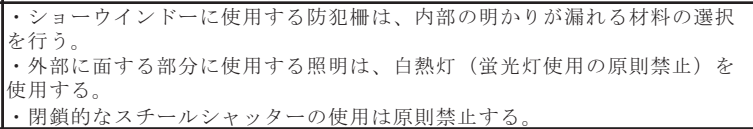 \\
\hline $\begin{array}{l}\text { 屋外に設 } \\
\text { 置する広 } \\
\text { 告物、空 } \\
\text { 調等の機 } \\
\text { 器、自動 } \\
\text { 販売機等 }\end{array}$ & 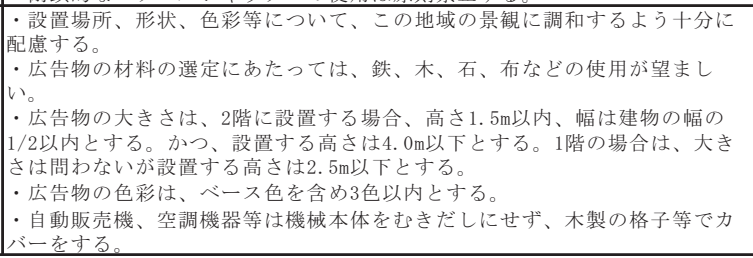 \\
\hline & 「総社商店街地区街なみ環境整備事業 街なみ環境整備方針報告書 \\
\hline
\end{tabular}


は 2 億 361 万 3 千円、補助額は 1 億 180 万 1 千円だった。補助金の 限度額は、表 5 のようになっており、住宅・店舗の新築、増改築の 限度額が最も高く設定された。対象となった建物は、全部で 37 棟注 11) となっており、建築物の補助金額は 39,681,500 円、外構は 16, 334, 900 円、屋根は 500, 000 円だった。修景物件のなかで、23 件の建物が建物と外構を合わせた一体的な建て替えによる修景を行 っており、外壁や屋根のみの修景事例はほとんどみられなかった。

\section{4.「街づくり協定」の達成度と課題}

ここでは、まず実際に実施された内容について時系列順に述べた 上で、表 4 の「街づくり協定」の内容と照らし合わせて、現地調查 をもとに、実際にどの程度達成できたのか、また区域内の修景され ていない建物も含めて総合的に問題点を抽出していく。

平成 9 年度から始まった街環事業では、最初の 3 年間で全修景物 件の内約半数の建物が修景された（表 8 )。平成 $9 \sim 10$ 年度では、建 物番号 $2 \sim 6$ や $8 \sim 10$ といった隣同士もしくは近接した建物において 修景が連続的に行われた。近くの建物同士で連続して実施されたこ とから相乗効果により一部の地区において街なみが改善されたこと は一定の成果があったといえる。その後は、小公園の整備と道路の 美装化が中心に行わ机、修景は毎年 $2 \sim 3$ 件程度の建物において実施 された。

(1)壁面後退（図 5・表 8): 街環事業開始前の市の調査によると、街 なみ環境整備促進区域内の道路総延長に対寸る区域内の幅員 $6 \mathrm{~m}$ 以 上の道路延長の占める割合が $6.12 \%$ となっており、幅員 $6 \mathrm{~m}$ 以上の 道路の割合が少ない。そこで、「街づくり協定」に壁面後退に関寸る 基準を設け、緊急車両の通過や火災時の対応等に配慮することにな った。具体的には商店街通りに面した建物は、 $2 \mathrm{~m}$ 以上の壁面後退を 行い、その敷地は植栽などにより整備するというものである。街環 事業以前には、接道不良住宅が田町地区で 9 件、本町地区で 24 件、

\section{表 5 補助限度額}

\begin{tabular}{|c|c|c|}
\hline & & 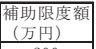 \\
\hline 住宅等の建築物 & 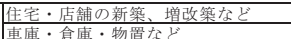 & \begin{tabular}{|l|}
200 \\
50
\end{tabular} \\
\hline 艚地の外構物 & 聞・塀・相・生垣・植裁・街灯など & $\frac{00}{66}$ \\
\hline $\begin{array}{l}\text { 号の他の工作物 } \\
\text { の修景 }\end{array}$ & 給排水設備・建築設備・広告物など & 66 \\
\hline $\begin{array}{l}\text { 外観に扮ける色 } \\
\text { 彩の修景 }\end{array}$ & 屋根・外壁・看板など & 50 \\
\hline
\end{tabular}

栄町地区で 7 件あり、

全体で $21.4 \%$ となっ ていた（表 2)。これは 街環事業の要件を満た
していないが、緊急車両が建物に近接できないため、街づくり協定」 において商店街通り以外の $4 \mathrm{~m}$ 以下の道路については、建築基準法に 定める幅員とすることが定められた。しかしながら、接道不良住宅 の整備については、実施されなかったため、現在も幅員 $4 \mathrm{~m}$ 以上の道 路に接していない建物が残存している（図 3)。

修景物件については、「街づくり協定」で定められている $2 \mathrm{~m}$ 以上 の壁面後退を満たしている建物がほとんどで、満たしていない建物 は 2 件のみであった（表 6)。そのうちの 1 件は、外構のみの修景と なっており、壁面後退が困難であったことがわかる。後退距離の基 準を満たしていない(19)番の建物については植木鉢などを建物前面に 設けており緑化に配慮していた（写真 3-19)。また、(4)番について は外壁面が雁行しており、凹んでいる部分にシンボルッリーなどの 植栽を植えていた。これらは一部において、ゆとりをもたせること ができていないが、緑化にはどちらも配慮していることがわかる(写 真 3-(4))。後退距離の短い建物では、横向きに車をとめているとこ ろがみられた（写真 3-24)。一方で、後退距離の長い建物では、20m 程度の壁面後退を行っている建物が 3 件あり、いずれも縦列駐車や 斜め駐車による駐車場となっていた。3 件とも店舗の駐車場となっ ており、過剩な壁面後退により街なみの連続性を失うことが懸念さ れるため、上限值を定めることも視野に入れる必要があると考える (写真 3-(22) 。後退した部分の用途としては、ほぼすべてが駐車場 と植栽、植木鉢による緑化だった。表 7 をみてみると、修景物件に おいては、17 件が建物前面に駐車場を設けていた。修景物件の多く は、壁面後退しているが、緑化した部分は車が出庫している時間帯 しかみることができないため、後退した空間の使われ方において問 題があると考えられる。こうした課題は、初期に修景された建物に おいてはほとんどみられなかったものの、事業の後半の時期におい て顕著にみられた。

商店街通り全体をみると、12 件の建物が 1 階を車庫にしていたが、 建物前面に駐車場を設けている事例は 29 件あり、非常に多いことが わかった（表 7)。修景物件以外の建物のみをみると、1 階を車庫に している建物や敷地内に駐車場を設けていない事例が多数みられた。 商店街通り全体の壁面後退の達成度をみると、36.1\%となっており、

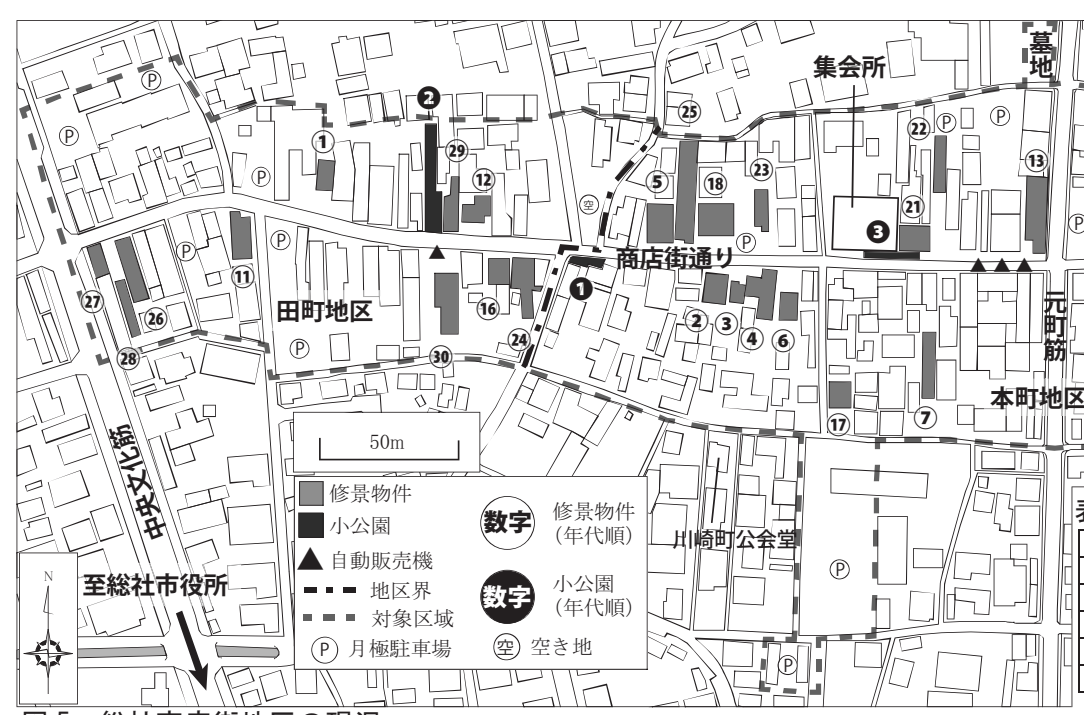

図 5 総社商店街地区の現況

- 白丸数字は修景物件の建物番号、黒丸数字は小公園の番号となっており、表 8 と対応してい る。

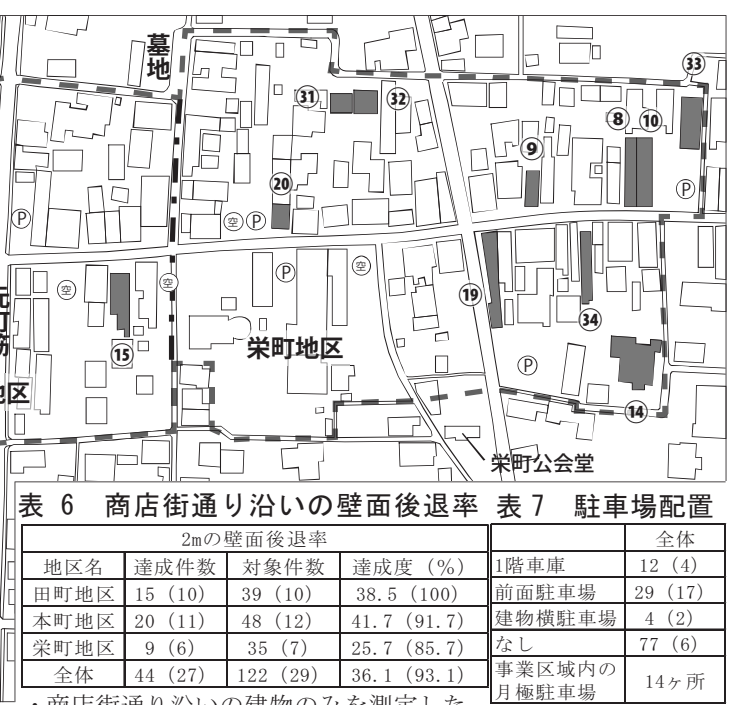

・商店街通り沿いの建物のみを測定した。極駐車場 ( ) 内は修景物件を示す。

商店街通り沿いに立 つ建物を対象とした。 
表 8 修景物件 · 小公園 - 道路の整備状況

\begin{tabular}{|c|c|c|c|c|c|c|c|c|c|c|c|c|c|c|c|c|c|c|c|c|c|}
\hline \multirow{3}{*}{$\begin{array}{l}\text { 事 } \\
\text { 業 } \\
\text { 名 }\end{array}$} & \multirow{3}{*}{ 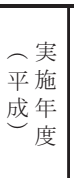 } & \multirow{3}{*}{\begin{tabular}{|l|} 
該 \\
当 \\
番 \\
号 \\
\end{tabular}} & \multirow{2}{*}{\multicolumn{4}{|c|}{$\begin{array}{l}\text { 事業内容 } \\
\text { 対象箇所 }\end{array}$}} & \multicolumn{5}{|c|}{ 基本事項 } & \multicolumn{10}{|c|}{ 特記事項 } \\
\hline & & & & & & & \multirow[b]{2}{*}{$\begin{array}{l}\text { 敷地 } \\
\text { 面積 } \\
\left(\mathrm{m}^{2}\right)\end{array}$} & \multirow[b]{2}{*}{$\begin{array}{l}\text { 建築 } \\
\text { 面積 } \\
\left(\mathrm{m}^{2}\right)\end{array}$} & \multirow[b]{2}{*}{$\begin{array}{l}\text { 延床 } \\
\text { 面皘 } \\
\left(\mathrm{m}^{2}\right)\end{array}$} & \multirow[b]{2}{*}{ 階 } & \multirow[b]{2}{*}{ 構造 } & \multicolumn{2}{|r|}{ 壁面後退 } & \multirow[b]{2}{*}{$\begin{array}{l}\text { 色彩（マ } \\
\text { ンセル } \\
\text { 值） }\end{array}$} & \multicolumn{2}{|c|}{ 外壁材等 } & \multirow{2}{*}{\begin{tabular}{|c|} 
門・塀 \\
木製 \\
シャッ \\
ター
\end{tabular}} & 屋 & & & \\
\hline & & & \begin{tabular}{|l} 
建 \\
筑 \\
物
\end{tabular} & \begin{tabular}{|l|} 
外 \\
構
\end{tabular} & \begin{tabular}{|l|l|} 
外 \\
壁
\end{tabular} & \begin{tabular}{|l|} 
屋 \\
根
\end{tabular} & & & & & & $\begin{array}{l}\text { 後退 } \\
\text { 距離 } \\
(\mathrm{m})\end{array}$ & $\begin{array}{c}\text { 後退した部分の } \\
\text { 利用状況 }\end{array}$ & & \begin{tabular}{|l} 
漆 \\
滄
\end{tabular} & \begin{tabular}{l|} 
木製 \\
格子
\end{tabular} & & $\begin{array}{l}\text { 勾 } \\
\text { 配 }\end{array}$ & $\begin{array}{l}\text { 瓦 } \\
\text { 材 }\end{array}$ & $\begin{array}{l}\text { 主要 } \\
\text { 用途 }\end{array}$ & 備考 \\
\hline & & (1) & 0 & 0 & & & 319.0 & 71.8 & 167.8 & 3 & 軽量鉄骨造 & 3.6 & 駐車場、植木鉢 & N9. 5 & 0 & - & - & 0 & - & 住宅 & \\
\hline & & (2) & 0 & 0 & & & 339.2 & 128.3 & 250.4 & 2 & 鉄骨造 & 2.3 & $\begin{array}{l}\text { シンボルツ } \\
\text { リー、商品置き } \\
\text { 場、植木鉢 } \\
\end{array}$ & $5 \mathrm{R} 9 / 0.5$ & $x$ & - & - & $\bullet$ & $x$ & 店舗 & 鎧張り \\
\hline & & (3) & 0 & 0 & & & - & - & - & 2 & - & 5.1 & \begin{tabular}{|l|} 
シンボルツ \\
リー、植栽 \\
\end{tabular} & N9. 5 & $\bullet$ & - & - & $\bullet$ & - & 住宅 & \\
\hline & 9 & (4) & & 0 & & & - & - & - & 2 & - & $1.3 *$ & $\begin{array}{l}\text { シンボルツ } \\
\text { リー、植栽 }\end{array}$ & N9 & $\bullet$ & - & - & $\bullet$ & - & 住宅 & 外壁下部レンガ \\
\hline & & (5) & 0 & 0 & & & 298.2 & 168.6 & 203.2 & 2 & 木造 & 4.1 & 植栽 & N9. 5 & - & - & - & - & - & 住宅 & $\begin{array}{l}\text { 市の木、住宅・ } \\
\text { 車庫・倉庫を一 } \\
\text { 体化 }\end{array}$ \\
\hline & & (6) & & 0 & & & - & - & - & 2 & - & $7.9 *$ & 駐車場、植裁 & 5 YR $8 / 2$ & $x$ & - & - & 0 & $x$ & 空き家 & 宝形屋根 \\
\hline & & (7) & 0 & & & & 306.6 & 43.2 & 86.4 & 2 & 木造 & 7 & 工 & N7.5 & $x$ & - & - & - & - & 住宅 & 珠藻土の壁 \\
\hline & & (8) & 0 & 0 & & & 164.8 & 118.7 & 174.1 & 2 & 鉄骨造 & 2.0 & 植木鉢 & N9. 5 & $\bullet$ & $\bullet$ & - & - & - & \begin{tabular}{|l|} 
店舗併用 \\
住宅
\end{tabular} & 蔵風の外観 \\
\hline & 10 & (9) & 0 & 0 & & & 120.6 & 84.1 & 151.3 & 2 & 木造 & 2.0 & 植裁 & N9 & 0 & - & - & - & 0 & 住宅 & \\
\hline & & (10) & 0 & 0 & & & 286.0 & 217.1 & 314.9 & 2 & 木造 & 2. 1 & なし & N9. 5 & - & - & - & $\bullet$ & - & \begin{tabular}{|c|} 
店舗併用 \\
住宅 \\
\end{tabular} & 本瓦莫き \\
\hline & & (11) & 0 & 0 & & & 157.3 & 94.2 & 201.4 & 3 & 木造 & 2.0 & 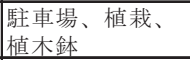 & N9 & $\bullet$ & $x$ & - & $\bullet$ & - & 住宅 & \\
\hline & & (12) & 0 & 0 & & & 348.0 & 222.6 & 400.2 & 2 & 木造 & 2.0 & 植栽 & N9. 5 & 0 & - & - & - & - & 住宅 & \\
\hline & & (13) & 0 & 0 & & & 274.0 & 128.5 & 199. 8 & 2 & 木造 & 2. 0 & 植栽 & N9. 5 & $\bullet$ & - & - & $\bullet$ & - & $\begin{array}{l}\text { 事務所併 } \\
\text { 用住宅 }\end{array}$ & \\
\hline & & (14) & & & 0 & & 465.5 & 68.3 & 68.3 & 1 & 木造 & 7 & 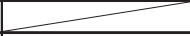 & $5 Y 9 / 1$ & $x$ & - & - & - & 0 & 住宅 & \\
\hline $\begin{array}{l}\text { 修 } \\
\text { 景 } \\
\text { 施 }\end{array}$ & 11 & (15) & & & & O & 226.0 & 75.9 & 136.4 & 2 & 木造 & $2.8 *$ & 駐車場 & N9. 5 & $\bullet$ & - & - & - & - & 住宅 & 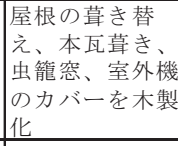 \\
\hline 設 & 12 & (16) & 0 & 0 & & & - & - & - & 2 & - & 4.7 & 植裁、駐車場 & N9. 5 & 0 & - & - & 0 & 0 & 住宅 & 二世帯住宅 \\
\hline 整 & 15 & (17) & 0 & 0 & & & - & - & - & 2 & - & 7 & 2 & N9. 5 & 0 & - & - & 0 & 0 & 住宅 & \\
\hline 備 & & (18) & & 0 & & & 157.7 & 75.9 & 144.4 & 2 & 鉄骨造 & $4.4 *$ & 植栽 & N9 & $x$ & 0 & - & $\times$ & $x$ & 住宅 & 市の木、市の花 \\
\hline & & (19) & 0 & 0 & & & - & - & - & 2 & - & 0.6 & 植木鉢 & N9. 5 & $\bullet$ & $\times$ & - & $\bullet$ & - & 住宅 & \begin{tabular}{|l} 
竹垣、側面は焼 \\
き板
\end{tabular} \\
\hline & & (20) & & 0 & & & 101.6 & 59.4 & 59.4 & 1 & 木造 & $5.0 *$ & 駐車場、植木鉢 & N9 & $x$ & - & $x$ & 0 & $x$ & 店舗 & \\
\hline & 16 & (21) & 0 & 0 & & & - & - & - & 2 & - & 2. 3 & 植栽、植木鉢 & N9. 5 & $\bullet$ & - & - & - & - & 店舗 & $\begin{array}{l}\text { 隣の家を取得し } \\
\text { 一体化、海鼠 } \\
\text { 壁、虫籠空空 }\end{array}$ \\
\hline & & (22) & & 0 & & & 210.0 & 58.0 & 95.8 & 2 & $\begin{array}{l}\text { 木造棒パネ } \\
\text { ル構造 }\end{array}$ & $21.9 *$ & 駐車場、植栽 & 2. 5 YR $8 / 3$ & $x$ & $\times$ & - & - & $\bullet$ & 住宅 & 板塀 \\
\hline & & (23) & 0 & 0 & & & 234.2 & 85.4 & 148.4 & 2 & 木造 & 7.0 & 駐車場、植栽 & 5 YR9/1 & 0 & - & - & 0 & - & 住宅 & \\
\hline & 17 & (24) & 0 & 0 & & & 519.2 & 254.5 & 254.5 & 1 & 木造 & 2.2 & 駐車場、植栽 & N9. 5 & $\bullet$ & $\bullet$ & - & $\bullet$ & - & \begin{tabular}{|l|} 
店舗併用 \\
住宅 \\
\end{tabular} & 虫籠空 \\
\hline & & (25) & & 0 & & & - & - & - & 2 & - & $5.3 *$ & 駐車場 & N9. 5 & 0 & 0 & $x$ & 0 & 0 & 住宅 & \\
\hline & & (26) & 0 & 0 & & & 377.9 & 74.3 & 99.3 & 2 & その他 & 5.9 & 駐車場、植裁 & 5 YR9/1 & $x$ & 0 & - & 0 & 0 & 住宅 & \\
\hline & 18 & (27) & 0 & 0 & & & - & - & - & 2 & - & 2.6 & $\begin{array}{l}\text { 駐車場、植栽、植木鉥 } \\
\end{array}$ & N9 & $\bullet$ & - & - & - & - & 住宅 & \\
\hline & & (28) & 0 & 0 & & & - & - & - & 1 & - & 18.1 & 駐車場、植栽 & N9. 5 & $\bullet$ & $\bullet$ & - & - & - & $\begin{array}{c}\text { 店舗併用 } \\
\text { 住宅 }\end{array}$ & \\
\hline & 19 & (29) & 0 & 0 & & & - & - & - & 2 & - & 2.5 & 植裁 & N2 & 0 & 0 & - & 0 & 0 & 住宅 & \\
\hline & 20 & (30) & 0 & $\bigcirc$ & & & 326.0 & 109.9 & 176.9 & 2 & 木造 & 9.5 & $\begin{array}{l}\text { 駐車場、植栽、動 } \\
\text { 自動販売機 }\end{array}$ & N9. 5 & - & - & - & - & $\times$ & \begin{tabular}{|c|} 
店舗併用 \\
住宅 \\
\end{tabular} & \\
\hline & 20 & (31) & & 0 & & & 98.6 & 29.8 & 59.6 & 2 & 木造 & $\gamma$ & 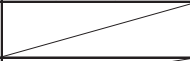 & N9 & $\bullet$ & - & - & $\bullet$ & - & $\begin{array}{c}\text { 自家用倉 } \\
\text { 庫 } \\
\end{array}$ & \\
\hline & 21 & (32) & & 0 & & & - & - & - & 2 & - & 7 & 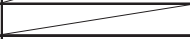 & 5YR8 $/ 2$ & $x$ & - & - & - & - & $\begin{array}{l}\text { 住宅 } \\
\end{array}$ & 市の木、市の花 \\
\hline & 23 & (33) & 0 & 0 & & & 341.3 & 93.6 & 150.7 & 2 & 木造 & 23.1 & 駐車場、植裁 & N9 & $\bullet$ & $\bullet$ & - & $\bullet$ & - & \begin{tabular}{|l|} 
店舗併用 \\
住宅
\end{tabular} & 本瓦苟き \\
\hline & & (34) & 0 & 0 & & & - & - & - & 1 & - & 5.2 & 駐車場、植栽 & N9. 5 & 0 & $x$ & - & - & - & $\begin{array}{l}\text { 住宅 } \\
\end{array}$ & \\
\hline 小 & 12 & (1) & & & & & & & & & 六枚 & 橋小公㝨 & 袁整備 $23.5 \mathrm{~m}^{2}$ & & & & & & & & $\begin{array}{l}\text { 石のベンチ、親 } \\
\text { 水空間 }\end{array}$ \\
\hline 公 & 14 & & & & & & & & & & & 用地 & 取得 & & & & & & & & \\
\hline 濑 & 16 & 2 & & & & & & & & & & 田町小公 & 公園整地 & & & & & & & & \\
\hline 篊 & 19 & & & & & & & & & & 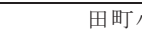 & 小公園整 & 擎備 $276.68 \mathrm{~m}^{2}$ & & & & & & & & 東屋、水路 \\
\hline & 22 & (3) & & & & & & & & & 本町ふ & れあい公 & 公園整備 $53.0 \mathrm{~m}^{2}$ & & & & & & & & 石のベンチ \\
\hline 道 & 13 & & & & & & & & & & & 測量 · & • 設計 & & & & & & & & \\
\hline 路 & 21 & & & & & & & & & & 道路改 & 良187.11 & $\mathrm{m}$ (田町地区) & & & & & & & & \\
\hline 装 & 22 & 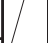 & & & & & & & & & 道路改 & 良295.4r & m（本町地区） & & & & & & & & \\
\hline 化 & 23 & & & & & & & & & & 道路改 & 良124.0! & m（栄町地区） & & & & & & & & \\
\hline
\end{tabular}

・総社市建築住宅課建築指導係所蔵「建築計画概要書」及び総社商店街地区街づくり協定運営委員会「総社商店街地区街なみ環境整備事業 15 年の歩み」より 作成。歩みは、実際に修景した建築物の建築主に事業終了後配布された。

・届出がない建物や確認申請が開始される以前に建てられた建物については、建築計画概要書がないため、面積等が不明である。後退距離については、商店街 通りに面している建物を対象とし、建築計画概要書がない建物は、実測調查を行った。また、外壁面から道路境界までの距離が短いところを計測し、米は建築 物の後退ではない物件である。斜線は、商店街通りに立地していない建物を示す。木製格子、木製シャッターの闌のハイフンは、格子やシャッターが設けられ ていない建物を示す。 
修景物件における道路拡幅という課題は解決しているものの街な み全体としての道路拡幅にはまだ問題があるといえる（表 6)。 (2)色彩（図 6・表 8): 「街づくり協定」における色彩の整備方針は、 無彩色の外壁を基本とし、有彩色の場合でも彩度を 2 以下とする ことが定められた。有彩色の色相 10 色全てにおいて彩度 2 以下と する基準は、非常に厳しい基準といえる。また、広告物の色彩に ついてもベース色を含め 3 色以内とするなど具体的な数值や配色 が定められた。ここでは通り沿いの景観で最も目につきやすい外 壁の色について検討していく。調查は、表 9 のように行った。

修景物件の外壁の多くは、N9〜N9.5 の無彩色で塗られており、 特に白色の漆喰が多くみられた（写真 3-8(10)。これは、「街づく り協定」において、外壁面積の $25 \%$ 以上を漆喰又はこれに類する 仕上げと寸ることが求められているためである。外構のみの修景 となっている建物では、彩度 2 を超える建物が 1 件確認できた(写 真 3-(22)）。厳しい基準のなかで外壁の修景を行ったすべての建物 が基準を満たしていたことは、一定の成果があったといえる。

街なみ全体についてみてみると、彩度 2 以下の基準を満たして いない建物が点在している。特に商店街通りに面して立地してい る傾向にある (写真 4-I )。漆喰等の無彩色の材料が推奨される なかで、有彩色の色彩で塗られた外壁も数多く点在している。街 なみ全体の達成度をみてみると、彩度 2 を超える建物が点在して いるもののどの地区においても 9 割以上の達成度となっており、 統一された街なみとなっていることがわかる（表 10）。

(3)外壁材等（表 8)：ここでは、外壁の仕上げと格子について明ら かにする。「街づくり協定」では、外壁面積の $25 \%$ 以上を漆喰ま たは、これに類する仕上げとすることが望ましいとされた。また、 格子については木製と寸ることが推奨された。

\section{表 9 色彩調査の概要}

\begin{tabular}{|c|c|}
\hline 調查日 & 平成 28 年4月 \\
\hline 天候 & 晴氺 \\
\hline 時間 & 午前11時〜午後3時 \\
\hline 使用色 & 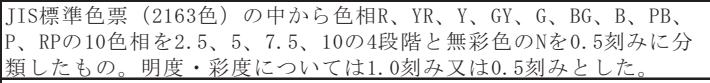 \\
\hline 測色方法 & 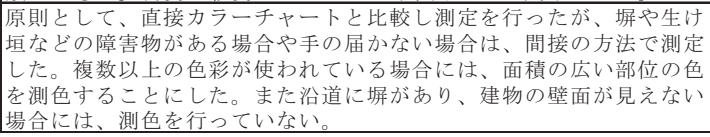 \\
\hline
\end{tabular}
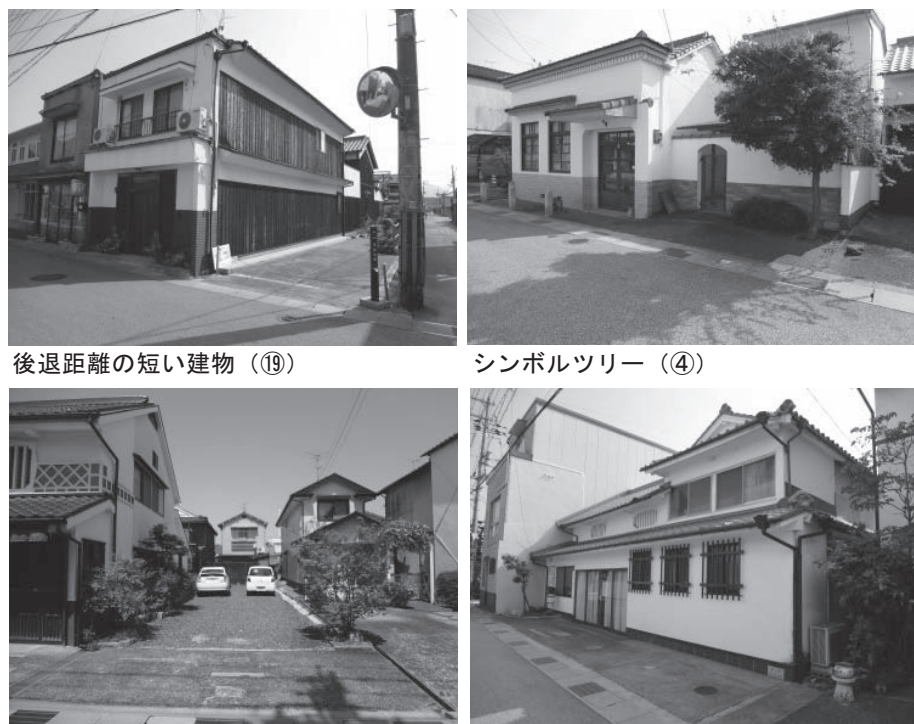

後退距離の長い物件（22）
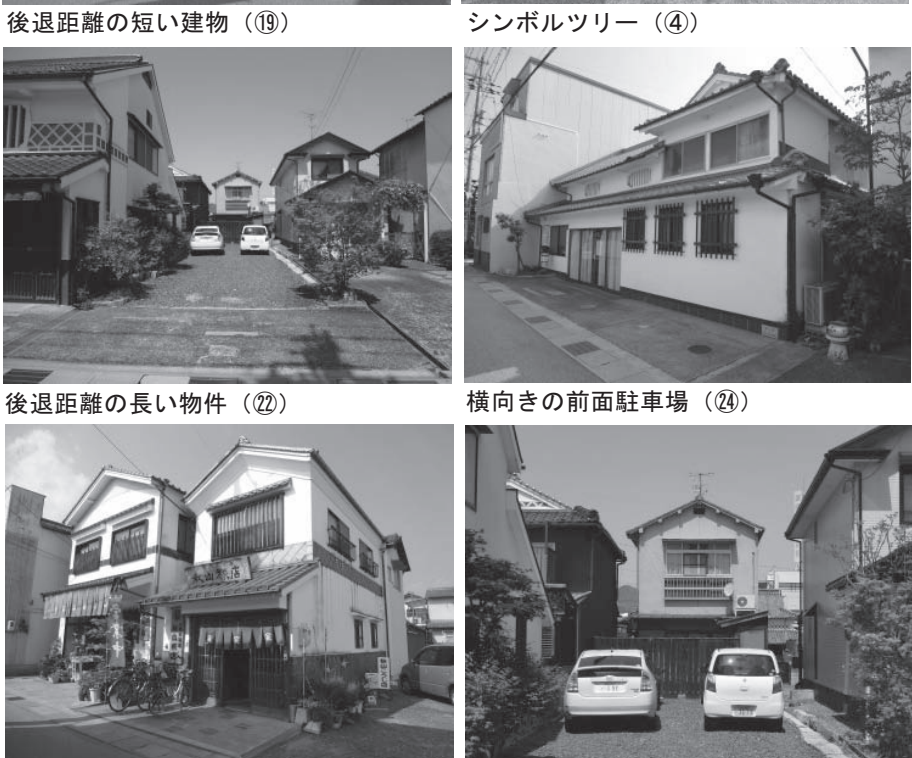

漆喰仕上げ（左(8)・右(10)

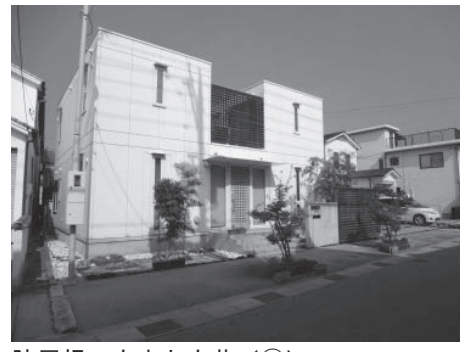

陸屋根・市木と市花 (18)

写真 3 修景の事例

・平成 28 年 4 月 15 日に筆者が撮影したものである。丸番号は、図 5 ・表 8 と対応 している。
横向きの前面駐車場（24）

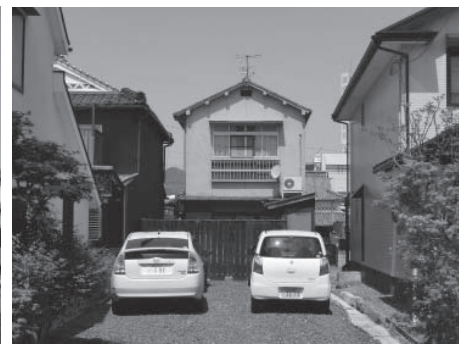

彩度 3 の建築物（22）

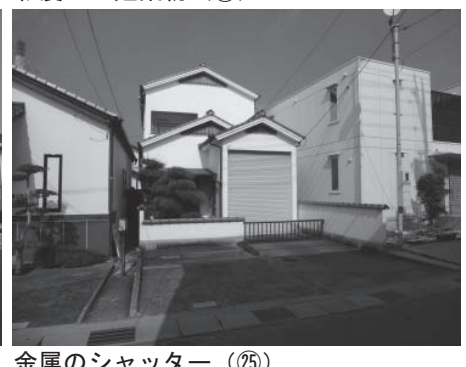

金属のシャッター (25)

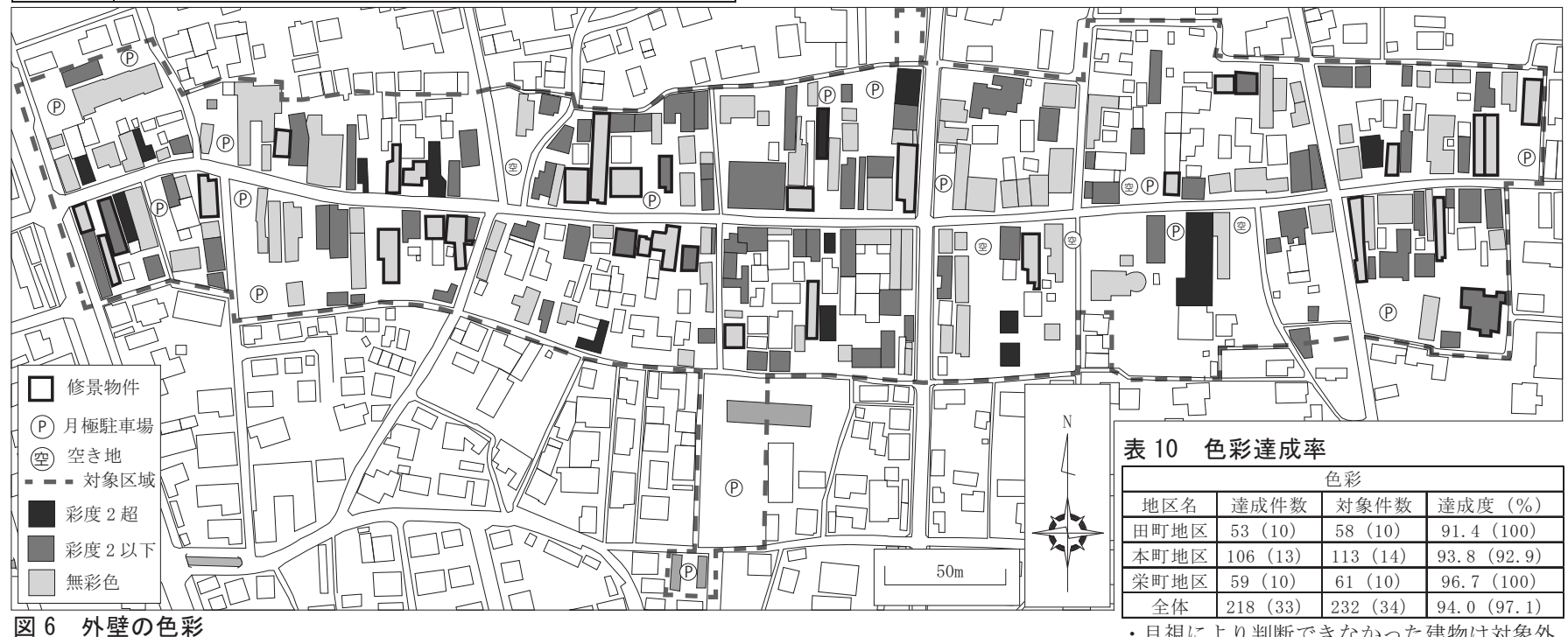

図 6 外壁の色彩

・通りに面する外壁で最も面積の大きい色を計測した。道路に接する面が 2 面以上の場合は、幅員の広い道路側としている。内は修景物件を示す。

の外壁の色を測定した。塀等により通り沿いから目視できない外壁は計測対象外とする。 
修景物件のなかで、建築物および外壁が対象部分となっている建 物についてみてみると、4 件を除いてほとんどが漆喰塗りとなって いた。漆喰塗りとなっていない外壁のうち 3 件は無彩色ともなって おらず、今後の課題としてあげられる。また、外構のみが修景対象 となっている建物の多くは、漆喰塗りとなっていないことがわかっ た。格子については、設けている建物が半数程度で、設けている建 物のなかでは 4 件が木製化していなかった。木製化している建物の なかでも既存の街なみにある伝統的な格子ではなく、クロス格子等 になっている建物もあり、統一化が図れていなかった。

街なみ全体についてみてみると、漆喰塗りとなっていない建物が 多く、サイディングやタイルなど漆喰以外の外壁仕上げがほとんど で、統一性のない街なみとなっている。また、江戸期の建物のなか には、老朽化した建物もあり、「昔の風情を残した街なみの保全」を 行っていく上で、伝統的建造物の外壁の塗り直しも今後必要となっ てくるだろう。格子については、修景物件以外では、地区内に格子 を設けた建物がほとんどなく、外壁面に木材をできるだけ使用する という「街づくり協定」とは異なる街なみとなっている。街なみ全 体の達成度をみても、格子を設けている建物を対象とした調查では 木製化している割合は 6 割程度となっており、格子を用いていても 木製化していない建物が目立っている（表 11）。

(4)門・塀（表 8）：「街づくり協定」では、車庫のシャッターは木製 等でつくることが望ましいとされ、植栽を行う場合は、市の木や市 の花を含めることが望ましいとされた（写真 3-18)。

修景物件のなかで車庫を設置している 2 件は、すべて金属材のシ ヤッターとなっており、配慮していないことがわかった (写真 3-(25)）。

地区全体では、金属材のシャッター付きの車庫が商店街通り沿い に多数設置されている（表 12）。市の木、市の花についても数件点 在している程度で、設置されていない（表 8)。

(5)屋根（表 8)：「街づくり協定」では、屋根形状は 4 寸勾配とし、 材料を瓦とすることが望ましいとされた。勾配の角度を計測するこ とが困難なため、ここでは勾配の有無と材料が瓦であるか検証する。

修景物件のなかでは、勾配屋根以外の陸屋根の建物は(18)番の 1 件 しかなく、ハウスメーカーが設計した建物だった（写真 3-(18)。(18)
表 11 木製格子

\begin{tabular}{|c|c|c|c|}
\hline \multicolumn{5}{|c|}{ 木製格子 } \\
\hline 地区名 & 達成件数 & 対象件数 & 達成度 (\%) \\
\hline 田町地区 & $7(5)$ & $11(6)$ & $63.6(83.3)$ \\
\hline 本町地区 & $6(6)$ & $7(7)$ & $85.7(85.7)$ \\
\hline 栄町地区 & $4(4)$ & $10(6)$ & $40.0(66.7)$ \\
\hline 全体 & $17(15)$ & $28(19)$ & $60.7(78.9)$ \\
\hline
\end{tabular}

・商店街通り沿いに立地する建物の内、 格子を設置している建物をカウントし た。（）内は修景物件を示す。
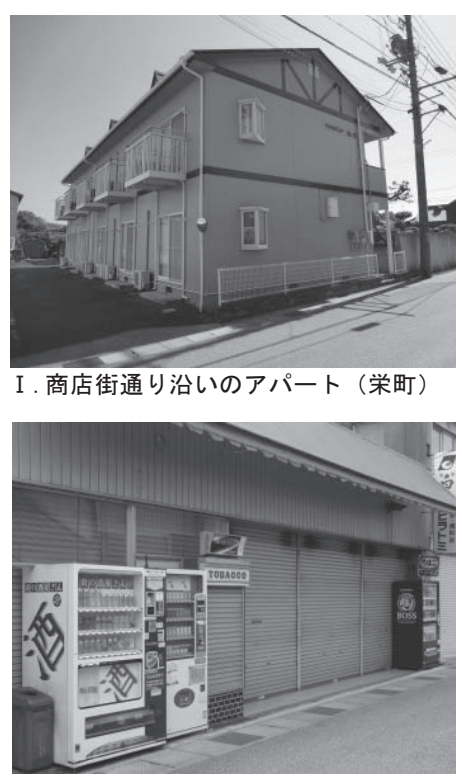

III. 集会所前の自動販売機

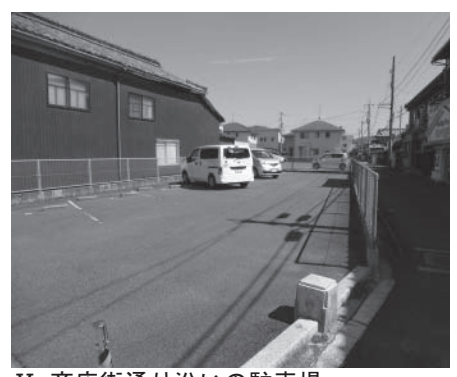

V. 商店街通り沿いの駐車場

写真 4 景観に関係する要素
表 12 木製シャッター

\begin{tabular}{|c|c|c|c|}
\hline \multicolumn{5}{|c|}{ 木製シャッター } \\
\hline 地区名 & 達成件数 & 対象件数 & 達成度 $(\%)$ \\
\hline 田町地区 & $0(0)$ & $7(0)$ & $0(0)$ \\
\hline 本町地区 & $0(0)$ & $22(1)$ & $0(0)$ \\
\hline 栄町地区 & $0(0)$ & $12(1)$ & $0(0)$ \\
\hline 全体 & $0(0)$ & $41(2)$ & $0(0)$ \\
\hline
\end{tabular}

・商店街通り沿いに立地する建物の内、 ヤッターを設置している建物をカウ

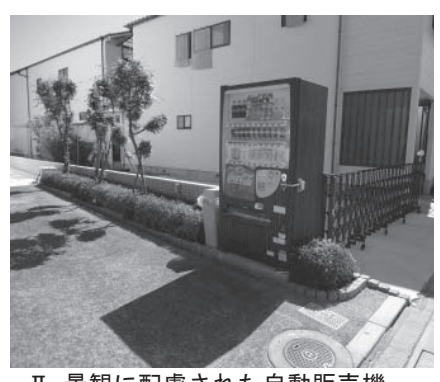

II. 景観に配慮された自動販売機

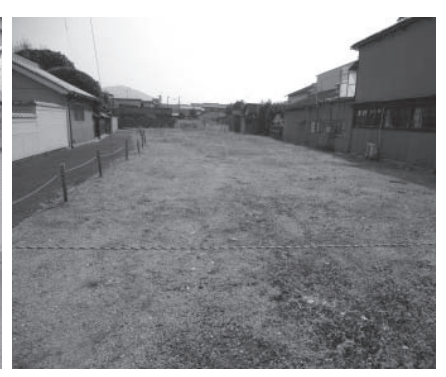

IV. 空き地

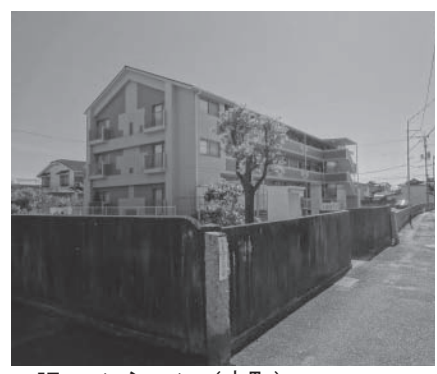

VI. マンション（本町）

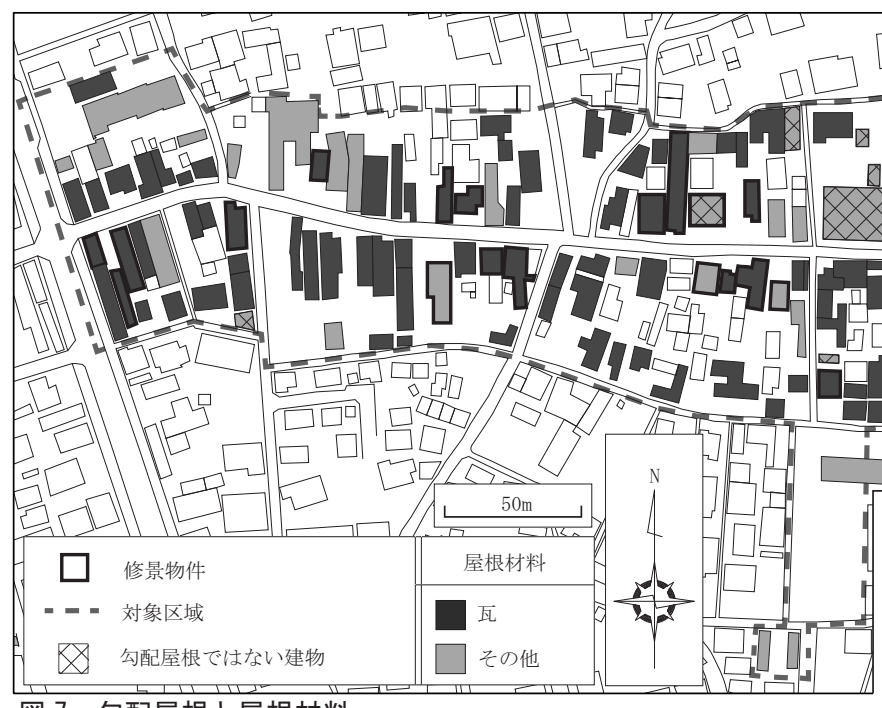

図 7 勾配屋根と屋根材料

・現地調査及び航空写真をもとに作成した。目視で確認できない屋根につい

ては、対象外とする。屋根材料のなかでスレート瓦等の特殊な形状の瓦は瓦

に含めない。 
番の建物については、修景部分が外構のみに限られていたため、陸 屋根になったと考えられる。屋根材については、瓦を使用している ところが多いが、瓦以外の材料を使用している建物も5 件みられた。 街なみ全体をみると、陸屋根は本町や栄町に一定数分布していた (表 13 ・図 7)。本町や栄町は、明治・江戸期の建物が多く残ってい るため、屋根を統一化していくことで伝統的街なみの保全につなげ ていく必要がある。

(6)建築物以外の要素（図 5): 自動販売機は、機械本体をむきだしに せず、木製の格子等でカバーすることが求められた。地区内の自動 販売機は 4 台設置されており、小公園の前に設置されている自動販 売機は、茶色の木目調のデザインとなっている (写真 4-II )。また、 通りに対して側面を向けており、景観に配慮していることがわかる。 一方で、集会所の近くに設置されている自動販売機は、一般的な自 動販売機で景観に配慮されていない（写真 4-III)。地区内には、空 き地が一部にみられ、街なみの連続性が阻害されている（図 5 ・写 真 4-IV)。特に区域の東側が多く、伝統的建造物が多く残る栄町の 街なみを阻害している。月極駐車場等については、商店街通りに面 して駐車場がつくられているところが多く、街なみの連続性が失わ れている (写真 4-V)。一方で、以前は大規模な月極駐車場として 利用されていた敷地が街環事業の計画にはなかったが、現在マンシ ヨンとなっている敷地がある（写真 4-VI）。このマンションは、切 妻屋根となっているものの 3 階建てで東西方向に長く立地しており、 景観を阻害しているといえる。

\section{5. 地区施設等の整備}

地区施設等の整備は、（1）生活道路、（2）小公園、（3）コミュニ
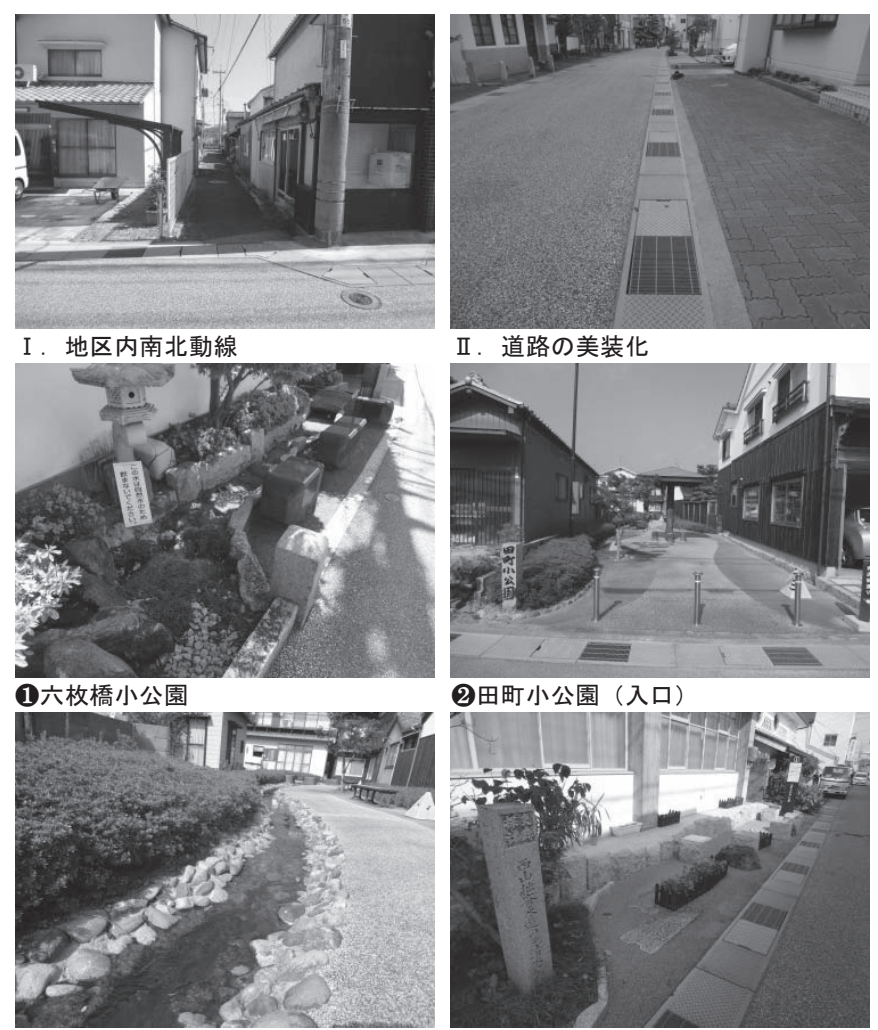

2田町小公園（小公園内の水路）

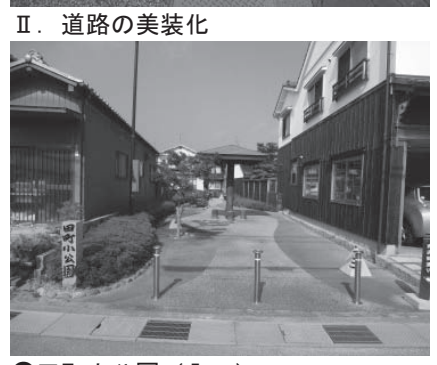

2田町小公園（入口）

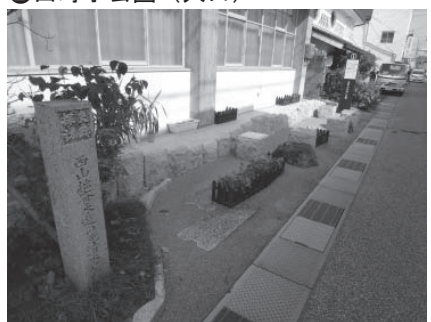

写真 5 地区施設等の整備

・平成 27 年 10 月 24 日に筆者が撮影したものである。黒丸番号は、図 5 ・表 8 と対応している。
ティ施設、(4) 道路の付属施設注12) の 4 つに分けて計画された。こ こでは具体的な計画案を整理した上で、問題点を抽出していく。

（1）生活道路：生活道路の整備として、道路の隅切を整備し、円滑 な動線を確保する (図 3-i)。また、地区内の南北動線を整備し(写 真 5- I )、接道不良住宅を改善するための生活道路を 2 本整備する ことが計画された（図 3)。

実現した計画として、商店街通りはアーケードの撤去にともない 平成 21 年度〜23 年度に住宅等の修景に配慮し、石灰石の入った白 色系の舗装や側溝の改修を行った（表 8、写真 5-II)。道路の美装化 については、 3 年計画で実施し商店街通りを一体的に整備している。 一方で商店街通りに接するほぼすべての小路の舗装・拡幅や地区内 の南北動線については、実現しておらず、整備予定だった 2 本の生 活道路は細い道のままとなっている。なかには歩行者がすれ違えな いほどの細い道もあり、地区内や南北を行き来する上で課題として 指摘できる。

（2）小公園（表 8）：地区内には、子どもの遊び場やお年寄りの憩 う公園や広場がなく、街環事業前の行政のアンケートでは、公園の 整備を期待する割合がもっとも高かったため、6 箇所の小公園を整 備することになった（図 3-i 〜 vi）。しかし、実際に整備された小 公園は 3 箇所のみとなった。実現された小公園で計画通りの位置に つくられたのは図 5 - 2 の 1 箇所のみであった。

実際に計画された小公園を順にみていく。最初に整備された公園 は、六枚橋小公園で本町地区の六枚橋が架かっている場所につくら れた（図 5-1 、写真 5- (1)。面積は 23.5 m²で非常に小さいが、石 のベンチが設置され、お年寄りが談笑できるスペースとなった。こ れは公共用地の一部において、景観を構成する親水空間として整備 する予定の場所であり、計画時は小公園として整備する予定ではな かった。2 番目に整備された小公園は田町小公園で、以前は空き地 となっていたところを、市が用地を取得した。敷地内には東屋や水 路が流れている（図 5-2、写真 5 - (2)。3つ目に整備された小公園 は、集会所の前のスペースにつくられ、以前商店街通りの側溝に使 われていた石蓋を再利用している（図 5-3、写真 5 - (3)。

しかし、街環事業実施後の地区内の公園面積の割合は、0.7\%とな っており、3\%未満のままとなっている。また、栄町地区には小公園 が整備されず、適正な配置とはなっていないことが指摘できる。

（3）コミュニティ施設（図 3・図 5)：本町地区の中央にある集会所 (カルチャーセンター) を改修する計画がたてられた。この集会所 は、昭和 59 年 8 月に郵便局だった建物を、市へ譲渡し、集会所とし て昭和 60 年に転用した。郵便局をそのまま転用したことにより、集 会所として利用しにくい点や施設そのものの老朽化が課題としてあ げられ、住民から整備が望まれたため、改修することになった。

しかしながら、実際に行われた整備として、集会所は外壁の塗り 直しが行われた程度で、室内の壁の位置を変更するなどの大規模な 改修には至らなかった。そのため、現在も郵便局の間取りのまま使 用されており、集会所としては使いにくい状態となっている。また、 構造も鉄筋コンクリート造 2 階建てとなっており、木造が多く建ち 並ぶ商店街通りにおける街なみの調和や景観への配慮も課題として 指摘できる。このように現在の集会所は、景観に対して配慮した点 はみられない。本町・田町地区の公共施設・コミュニティ施設の整 備は、実現しなかった。 


\section{6. おわりに}

本稿では、総社市商店街地区を事例に取り上げ、街環事業によっ て創出された空間の整備状況について「街づくり協定」に則して調 查、分析を行った。その結果をふまえて商店街地区の街なみにおけ る問題点を抽出し、「街づくり協定」における整備方針の達成度と妥 当性について検証した上で、今後に向けた提案について考察する。

「街づくり協定」では、全国の街環事業のなかでも数少ない道路 拡幅手法である壁面後退が導入された。建物を壁面後退することで 創出された空間は、通常の道路拡幅手法とは異なり、建物を壁面後 退させ、後退した空間を道路ではなく敷地として利用することによ り建物前面に半公共的空間をつくりだした。これにより、半公共的 空間を緑化することで、潤いとゆとりのある街なみ形成が可能とな った。しかしながら、ほとんどの修景物件で「街づくり協定」にお いて定められた $2 \mathrm{~m}$ の基準を確保しているものの、多くは後退した空 間を駐車場として利用しているため、緑化した部分がみえないこと が実情である。そのため、当初の目的であった「昔の風情を残した 街なみの保全」という点では課題が残っている。特に、区域の東側 には歴史的に価值の高い伝統的建造物が多く残っているため、街な みの保存に留意した景観整備が求められる。また、当地区は総社宮 の門前町として栄え、伝統的建造物と建て替えられた建物が混在し ていたことから色彩や材料といった部分で街なみとしての統一性を

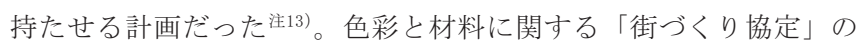
整備方針は具体的な数值を用いた定量的な基準だったため、街なみ を統一化していく上では適正な設定だったといえる。しかしながら、 修景物件のなかでも「街づくり協定」を満たしていない建物も一定 数あったことから、「街づくり協定」の整備方針について今後再検討 する必要があると考えられる。

馝いの空間として小公園が 6 箇所整備される計画となっていたが、 実際に計画された小公園は 3 箇所のみで、区域の $0.7 \%$ しか確保で きていないことがわかった。特に、2 箇所の小公園については、か なり小規模なものになっていた。そのため、子どもの遊び場や地域 住民の数いの場として使いにくいことが確認された。

本稿では、壁面後退によって創出された半公共的空間を使った景 観整備について明らかにしてきた。この手法の最大の特徴は、建物 の修景と道路拡幅を同時に行い、半公共的空間を緑化することで、 街なみ全体の住環境・景観整備が図れる点にある。しかしながら、 後退した空間を駐車場にするといった半公共的空間の使い方に課題 があるため、今後「街づくり協定」の整備方針の見直しを含めて再 考していく必要がある。この手法は、伝統的建造物が多く分布する 地区や接道不良住宅が多く分布する地区に応用できる可能性があり、 半公共的空間の一部を緑化することで街なみ全体の住環境・景観整 備につながることが期待される。事業全体の特徴として、最初の 3 年間に全修景物件のうち約半数が実施された。その多くは、隣同士 もしくは近接した建物において修景が連続的に行われ、近くの建物 同士で連続して実施されたことから相乗効果により一部の地区にお いて街なみが改善された。さらに、初期の修景事例は後退した空間 を緑化し駐車場を設けていなかったことから一定の成果があったと 考えられる。しかしながら、その後の修景物件は駐車場を設けるこ とが前提となっている建物が多いことから、今後他の地区で応用し ていく際には注意が必要である。色彩・材料の統一においては、一
定の成果が確認された。本事業は、修景が実施された建築物におい て一定の成果がみられたものの建築物以外の空間利用に関して課題 がみられたため、今後は修景整備後の空間利用についても検討する 必要がある。具体的には、後退した空間の緑化率等を定めることで 街なみの改善に対応していくことが必要となるだろう。

\section{謝辞}

本研究は科研費（特別研究員）（15J12478）の助成を受けたもので ある。総社市役所都市計画課及び建築住宅課、総社市図書館の職員 の方々に大変お世話になった。ここに記して感謝申し上げます。

\section{参考文献}

1）鵤心治ほか 2 名：街なみ環境整備事業における協働のまちづくりに関す る研究，日本建築学会技術報告集，第 19 号，pp. 271-274，2004.6

2）林直孝・浅野聡 : 歴史的地区の景観整備における街な夕環境整備事業と 景観施策の関係性に関する研究 - 東海 3 県を事例に -, 日本建築学会大 会学術講演梗概集, F-1 分冊, pp. 319-320, 2011.8

3）井上亮ほか 2 名：セットバック方式による戦後岡山市における中心市街 地の街路空間形成 一 街並み整備誘導指針にもとづく都市美造成の取り 組みを中心に一, 日本建築学会計画系論文集, 第 81 巻, 第 723 号, pp. $1133-1143,2016.5$

4）総社市 - 財団法人国土開発技術研究センター：総社商店街地区多機能交 流拠点整備事業調査報告書, 1991. 3

5）総社市: 総社商店街地区街なみ環境整備事業 街なみ環境整備方針報告 書, 1995.3

6）国土交通省住宅局：街な夕環境整備事業パンフレット 美しい景観、良 好な居住環境の形成のために，2009. 12

注

1）「街づくり協定」は、原則として促進区域内の一定の地区内の土地所 有者等の全員の合意によって締結されることが望ましいものである。 ただし、地区住民の合意形成が十分と認められ、良好な住宅等及び地 区施設の整備が確実であれば $2 / 3$ 以上の合意で締結されていればよい。 なお、総社市商店街地区では 303 人中 246 人が合意しており、81. $19 \%$ の割合となっている。「街づくり協定」の有効期間は、15 年以上とな つている。

注2）佐藤圭二「愛知県における防災まちづくりの必要地区調査および防災 まちづくりの全国先進事例調査」(公益財団法人 日比科学技術振興財 団研究報告書、2005）では、住宅改善と道路拡幅新設事業が少ないこ とを指摘している。地元地権者や関係機関と協力して建物修景と道路 拡幅を同時に行う事業として沿道区画整理型街路事業、シンボルロー ド整備事業などがあるが、いずれも大規模な道路拡幅で一般的に通り 全体の建物を後退させる手法である。

注3）「壁面後退」および「セットバック」は、ともに外壁を後退させると いう意味をもつが、「セットバック」には、建物上部を段状に後退させ ること、道路幅員の確保などといった意味ももつため、本稿では敷地 の境界線から外壁を後退させる行為は「壁面後退」とする。

注4）平成 2 年度に総社市が (財) 国土開発技術研究センターに委託して実 施した調査の成果をまとめたものである。

注5）本稿では、「商店街地区」を対象として扱っているが、現在は「商店街」 としての機能が失われ「住宅街」となっているため、「商店街」として の考察は行わないこととする。

注6）区域の形は、同意が得られた敷地が対象となっているため、複雑な形 状となっている。

注7）前掲「総社商店街地区多機能交流拠点整備事業調查報告書」（1991. 3） に掲載されている古写真より街なみの連続性が高いと判断した。

注8）総社市役所建設部都市計画課へのヒアリングによる。

注9）総社市「総社商店街地区街なみ環境整備事業 街なみ環境整備方針報 告書」（1995.3）より作成した。住宅総数は、敷地でカウントした。

注10）工場も含む。

注11） 2 棟以上の建物を一体化させて 1 棟にした建物も含まれるため、修景 された建物は 34 件である。

注12）公共用地の一部に親水空間が計画されたが、小公園として整備された ため、（2）小公園において記述している。

注13）前掲「総社商店街地区街なみ環境整備事業 街なみ環境整備方針報告 書」（p.71、1995.3）では、建築デザインの誘導として材料・色彩の統 一を重要視した計画だったことが記されている。 


\title{
LIVING ENVIRONMENT AND LANDSCAPE MAINTENANCE DUE TO RESTORATION AND SETBACK USING THE UNDERTAKING FOR TOWNSCAPE IMPROVEMENT
}

A case study on the Soja shopping streets area

\author{
Ryo INOUE* and Shigeo NAKANO** \\ * Assist. Prof., IFSE, Univ. Shimane, Ph. D. in Eng. \\ ** Prof., IFSE, Univ. Shimane, Ph. D. in Urban and Regional Planning
}

\begin{abstract}
Restoration undertakings with administrative support can lately be found not only in important preservation districts for groups of historic buildings but also in urban districts, and efforts are being made to maintain and preserve excellent townscapes and improve landscapes. One of the ways to undergo restoration is through receiving subsidies by meeting the requirements mandated by the Ministry of Land, Infrastructure, Transport and Tourism. In
\end{abstract} particular, undertakings for townscape improvement are based on "MACHIDUKURI agreements" concluded by the residents of a district, and are positioned as resident-driven undertakings.

Undertakings for townscape improvement characteristically involve building pocket parks, beautifying roads, and restoring housing, all of which are necessary to create excellent townscapes. However, only a few undertakings for townscape improvement have been integrally completed in combination with restoration of housing and widening of roads. Using setbacks is one of the approaches to widening roads, and the shopping district of Soja city is one of the districts that adopted this approach. There are no parks in the shopping district, and roads wider than six meters account for less than $10 \%$ of the total roads in the district. Therefore, setbacks of housing walls were planned and carried out. Instead of using the space created by the setbacks for roads, as stipulated in the Building Standards Act, the space created in the district was used as building lots. Creating a boundary area between a road, a public area, and housing, a private area, makes it possible to widen a road even in shallow premises. In this way, clarifying how a townscape created by a setback was restored and analyzing how it is being utilized can give clues for new planning methods for undertaking townscape improvement.

Consequently, it was made clear that most restored buildings failed to achieve the initial objective of "preserving townscape with traditional flavor" because the spaces created by the setbacks were used as parking lots, though they secured the two meters stipulated by the MACHIDUKURI agreement. Because the city's east side has many traditional buildings that are highly valuable from a historical viewpoint, the city is required to give consideration to preserving the townscape and building a continuous townscape. The same issue arises not only for buildings but also for open spaces and parking lots. It is also a problem that some buildings do not meet the color and roofing standards set by the MACHIDUKURI agreement. It was originally planned to build pocket parks and community facilities as spaces for relaxing, but only three pocket parks were eventually built. As a result, the total area of pocket parks accounts for only $0.7 \%$ of the whole area of the district. That is, the greatest problem of this undertaking is that the spaces for relaxing inside the district were scarcely improved, although restored buildings offered better living environments.

In the future, therefore, it will be crucial to increase residents' awareness of landscapes and townscapes in order to achieve a better living environment in districts with many traditional buildings. At the same time, it will be necessary to discuss measures not only for the restoration of each building but also for the improvement of the landscape of the whole townscape. 